\title{
In Search of Influence - Leading Knowledge Workers with Care
}

\author{
Ola Edvin Vie ${ }^{1}$ \\ ${ }^{1}$ Department of Industrial Economics and Technology Management, NTNU (Norwegian University of Science \\ and Technology), Trondheim, Norway \\ Correspondence: Ola Edvin Vie, Department of Industrial Economics and Technology Management, NTNU \\ (Norwegian University of Science and Technology), 7491 Trondheim, Norway. Tel: 47-7359-6340. E-mail: \\ ola.edvin.vie@iot.ntnu.no
}

\author{
Received: July 17, 2012 Accepted: August 17, 2012 Online Published: October 16, 2012 \\ doi:10.5539/ijbm.v7n20p13 \\ URL: http://dx.doi.org/10.5539/ijbm.v7n20p13
}

\begin{abstract}
Managers in Research and development (R\&D) are in search of influence because knowledge workers value autonomy and dislike direct supervision. The purpose of this article is to explore if and how leadership support is connected to influence. Through interviews with knowledge workers, it is evident that they expect their manager to be supportive and take an interest in them as complete persons. Observations and interviews with managers reveal that they fulfill these expectations by engaging in listening and chatting. In addition, the data also illustrates that managers care about their employees. The analysis shows that manager's activities of care can indeed be a source of social influence, illustrating close connection between emotion and influence. This intertwinement should inspire future research to look deeper and broader for potential sources of influence in the leadership process, but also to acknowledge the importance of leadership in the setting of innovation.
\end{abstract}

Keywords: care, leadership, R\&D, social influence

\section{Introducation}

The body of a manuscript opens with an introduction that presents the specific problem under study and describes the research strategy. Because the introduction is clearly identified by its position in the manuscript, it does not carry a heading labeling it the introduction. Before writing the introduction, consider the following questions (Beck \& Sales, 2001): Traditionally, leadership has not been perceived as an important source of influence on creativity and innovation (Mumford, Scott, Gaddis, \& Strange, 2002). This could probably explain why so little leadership research has been conducted in research and development (R\&D) organizations or contexts (Elkins \& Keller, 2003). R\&D organizations are very vulnerable to undesired turnover because they are extremely dependent on their employees' unique knowledge and expertise (Alvesson, 2000, 2004). To counter this vulnerability, many of these organizations try to increase or sustain their employees' commitment and loyalty. However, because creative people value autonomy (Mumford et al., 2002; Oldham \& Cummings, 1996) and dislike to be directed by a supervisor (McAuley, Duberley, \& Cohen, 2000), leaders of creative people cannot appear to be controlling without risking severe resistance and possibly undesired turnover. Therefore, it can be argued that R\&D managers are in search of influence.

Henry Mintzberg (1998) suggests that leadership needs to be indirect and covert because professionals require more support and less direct supervision. This resonates with more recent leadership research like George (2000), Dasborough and Ashkanasy (2002), and Dasborough (2006), arguing that emotions are central to leadership as a social influence process. Although few leadership scholars have given much attention to emotions (see Humphrey, 2002), others have recognized that the management in knowledge-intensive firms sometimes plays on emotions to accomplish normative control (Alvesson, 2004, p. 151; Kunda, 1992). However, neither of these accounts details how ordinary daily managerial activities in this setting are connected to influence of knowledge workers.

To explore this issue, an open and qualitative research strategy was chosen for this study, because of the relatively few leadership studies conducted in R\&D organizations (Elkins \& Keller, 2003). Qualitative research plays an important role in leadership research because of its ability and flexibility to explore the unexpected (Conger, 1998). Although the number of qualitative leadership studies has increased, observation methods have rarely been used; instead, conducting qualitative interviews is the preferred research method (Bryman, 2004). 
Conger (1998) has warned against over-reliance on interviewing as the only data source, and has encouraged the use of observation as a valuable method for data collection. Therefore the qualitative data in this study were collected both from interviews and observations.

The article is structured as follows. The first section after this introduction discusses leadership as intentional and unintentional influence, before reviewing leadership in R\&D organizations. Here, the review has a special focus on leadership support and emotions to explore how this may be related to social influence as indicated above. Afterwards the method applied in this study and the research settings are described, before the empirical findings are presented in the next section. The findings explore what knowledge workers expect of their manager, how the managers perceive these expectations, as well as what the managers do to fulfill these expectations. The following section analyses these managerial activities as social influence. The article ends with a discussion of the findings and the implication of this study.

\subsection{Leadership and Influence}

The elusive character of leadership is illustrated by the numerous and different definitions of the concept, but some common elements recur across definitions. Leadership is commonly understood as a process of intentional influence by one person over a group of people to accomplish a given goal (Bass, 1990; Yukl, 2002). A number of studies have examined proactive influence tactics, which are used to get someone to carry out requests (see Higgins, Judge, \& Ferris, 2003; Yukl, 2002; Yukl, Seifert, \& Chavez, 2008). Influence in this regard seems to be used as a synonym for persuasion, but while persuasion is consciously sought, influence may be unintentional (Hargie, Dickson, \& Tourish, 1999, p. 24). This implies that managerial activities and behaviour can influence people both intentionally and unintentionally. Therefore, leadership researchers should examine managerial influence from a broader perspective than influence tactics.

An alternative perspective is the framework by Cialdini (2001), which recognizes that the social influence process can also be subtle, indirect and outside of awareness (This is parallel to the view that emotions can be spread implicitly through emotional contagion (Hatfield, Cacioppo, \& Rapson, 1993).) A range of Cialdini's (2001) well-known principles of influence will be described and applied later in the analysis section, while the common premise for these processes is the focus in this section.

According to Cialdini (2001), people have a tendency to act according to fixed-action patterns, usually triggered by a single feature of relevant information in the situation. In a world with more information than people can handle, relying on such heuristics helps an individual choose a correct course of action without having to analyse the situation carefully. The disadvantage of reliance on an automatic pattern lies in its vulnerability to make silly and costly mistakes, which could be exploited by compliance professionals like salespersons. Because one of the main tasks of leadership is to influence others, it is possible to make the case that leaders are a type of compliance professional. However, different organizational settings would constrain both a leader's need and ability to induce influence. In this study, it is therefore necessary to give particular attention to leadership and influence in R\&D contexts and organizations.

\subsection{Leadership in Research and Development}

In the two-part special issues of The Leadership Quarterly on Leading for Innovation (2003-2004), one of the main conclusions is that leadership and leader behaviour makes a difference on innovation (Mumford \& Licuanan, 2004). Among the articles in these issues, we find an extensive review of leadership in R\&D organizations (Elkins \& Keller, 2003), which illustrates that the main focus has been on R\&D project groups and leaders. In the relatively few studies of leadership in R\&D organizations, a number of different approaches to leadership have been covered (see Elkins \& Keller, 2003; Farris, 1988; Scott \& Bruce, 1998). In the following section we will focus on some of the research examining transformational leadership and leader skills.

The concepts of transformational leadership was initiated by Burns (1978) and developed further by Bass (1985). The process of transformational leadership may be understood as a deliberate attempt to influence followers to support the organizations' vision and direction. This is accomplished by creating an environment of trust where the followers are empowered to achieve these goals, which in theory implicitly means enhanced follower performance. Bass and Avolio (1990) described four dimensions of transformational leadership: Idealized influence, Inspirational motivation, Intellectual stimulation and Individualized consideration.

In a study of top-level R\&D leaders by Jung, Chow and Wu (2003), transformational leadership was linked to organizational innovation measured as patent awards, as well as related to empowerment and supportive climate for innovation. The authors also suggested that a transformational leader increases follower's intrinsic motivation, which again leads to more creativity. In another study, Pirola-Merlo et al. (2002) found that a transformational 
leadership style could help to buffer the negative impacts from obstacles on R\&D teams. Together these studies point to the importance of emotions in the relationship between R\&D leaders and subordinates.

Usually, technical expertise and creative problem-solving skills are regarded as the most essential skills for leading creative people (Elkins \& Keller, 2003). Although acknowledging that technical skills were consistently positively related in previous research, Farris (1988) also pointed to the importance of having human relations skills and using the leader as a catalyst for the innovation process. Summarizing previous studies, he wrote: "Human relations skills are related positively but less consistently to group performance" (p. 14). Although a large number of studies have recognized the importance of leader support for subordinates' creativity (Mumford et al., 2002), leaders' capability to care has been recognized only by a few authors, like Sashkin (2004), who equals caring with demonstrating respect and concern for people. Interviewing R\&D leaders and employees about the spirit of their communities, Judge, Fryxell and Dooley (1997) noted that family feeling, trust and care were commonly used to describe the culture. For instance, a technician stated: "I like coming to work; we really care about each other here - it's not just a job" (p. 75). This suggests that care should be examined further, and we turn to this subject in the next section.

\subsection{Leading with Care}

Care has been conceptualized in various ways. Webster's dictionary defines care as "painstaking or watchful attention," while Oxford dictionary defines care as "serious attention, a feeling of concern and interest." Milton Mayeroff (1971, p. 1) has the following definition: "to care for another person, in the most significant sense, is to help him grow and actualize himself." Notice the similarity between this definition and Burns' (1978) definition of transformational leadership as "engagement with each other to raise one another to higher levels of motivation and morality."

The expression "to care for" is an ambiguous expression, which could refer to an activity, without necessarily containing emotion, or to a set of feelings, without necessarily being expressed through action (Solomon, 1998). The relational nature of care and the focus on taking other peoples' perspectives and understanding their meanings highlights why care has special relevance for sharing and creating knowledge. Von Krogh (1998) argues that care is essential for innovation in companies, because high-care relationships can overcome mistrust, fear and isolation and promote volunteer knowledge sharing. Care gives rise to mutual trust, active empathy, access to help, lenience in judgement, and courage (von Krogh, 1998; von Krogh, Ichijo, \& Nonaka, 2000).

In this review of leadership in R\&D organizations, we have highlighted the importance of leader support and some of the emotional aspects of this like care. To focus our investigation on these issues, we explore the situation of R\&D line leaders with personnel responsibility. Because these leaders do not have the day-to-day responsibility for completing projects, relationship-oriented actions should be more profound than task-oriented actions. We turn to the empirical findings after describing the method applied in this study and the research settings.

\section{Method}

\subsection{Data collection}

The qualitative data in this study were collected through interviews and observations following the structured observation method by Mintzberg, which he described as "a method that couples the flexibility of open-ended observation with the discipline of seeking certain types of structured data" (1973, p. 231). The method, which is also called shadowing, could be seen as a distinct research technique combining quantitative and qualitative approaches (McDonald, 2005). However, to counter the method's one-eyed managerial perspective, interviews with non-managerial employees are also necessary.

In addition to shadowing and observing four R\&D managers for one week each (totalling 191 hours), a total of 30 separate interviews were conducted. This includes interviews with all four managers both before and after the observation, with their superior, and with five of their subordinates. Only two superiors were interviewed because one of the shadowed managers was a second line manager above another, and because two of the shadowed managers had the same superior. Among the 20 subordinates interviewed, five were female, and eleven had project management experience. Everyone has been given male cover names to ensure anonymity. Data gathering took place in two main clusters of time, each concentrated on one of the two departments to benefit from continuity in the observation.

All interviews were prepared and conducted with the help of a semi-structured interview guide (Bryman, 2008; Kvale, 1996). Generally the informants were first asked to outline their own history and role in the company. The themes covered in this guide were the informants' preference of being managed, mutual expectations between 
them and their manager, and how they related to line and project managers. The most sensitive theme was how they perceived the managers. During the interviews the informants were often asked to elaborate on answers to probe issues outside the interview guide.

\subsection{The Participants and Their Organizations}

The two departments in this study are both part of companies that produce advanced technical products for an international market, and where R\&D activities are central. The two companies are very similar; in 2006 when the data were gathered, and each had operating revenues of approximately 400 Million Euros and approximately 2000 employees. The employees' age, gender and education are also similar in the two companies.

Both R\&D departments are part of larger divisions. The biggest one consists of about 150 employees in seven sections, while the smaller one has about 60 employees in four sections. Both companies are organized as matrix organizations. The biggest difference between the two is the size of the projects. While the largest department has been mainly involved with one giant project, the other department has many smaller projects.

The four shadowed managers are all males between 36 and 51 years with a Bachelors, Masters, or PhD degree in engineering. Three are first level managers, while one is a second-level manager. They have responsibility for between 12 and 60 persons. In average, they have been in the company for 14 years, have 7 years managerial experience, and have held their current positions for 3 years.

\subsection{Data Analysis}

The analysis process consisted of several steps. First, the preliminary data analysis involved reading through the interview transcripts and observational field notes several times in totality. The second phase consisted of sorting the structured observations into work activities, in the same manner as Mintzberg (1973). These quantitative findings are reported elsewhere (Vie, 2010). However, through this step of the analysis it became evident that the managers spent considerable time on showing concern and caring for their employees. This became the starting point for the third step.

This phase in the analysis process consisted of multiple reading of field notes and interview transcripts guided by a case study approach (Eisenhardt, 1989; Yin, 2002) and thematically analysis (see Bryman, 2008, p. 554ff). The object of this phase was to get a better understanding of why the managers cared, and involved analysis of the interviews with knowledge workers focused on their expectations regarding leadership in general and the relationship with their manager in particular. These expectations were later triangulated (Yin, 2002) with the manager's perceptions of the same issues. Through the interviews the managers indicated that hey were aware that showing care had some positive influencing effect. However, they had no idea how the process actually worked and the influence they generated seemed unintentional.

The previous phase in the analysis highlighted a need for a return to the literature for a theoretical concept to guide the analysis further to understand how care could influence others unintentionally. Reading up on the literature on influence it became evident that social influence theory (Cialdini, 2001), explaining how influence does not need to be intentional, was a good framework to shed more light on connection between care, R\&D leadership and influence. However, because the response from others influence would usually be unnoticeable it is extremely difficult to gather reliable empirical data that can prove a causal connection between a particular activity like care and a particular outcome. Therefore, the analysis of managerial influence is restricted to how managerial activities can lead to influence on knowledge workers, and not to a causal explanation. The analysis of social influence discusses the potential relevance of each dimension of influence (Cialdini, 2001) in the setting of this particular study of R\&D. However, before we turn to this analysis the empirical findings based interviews and observation will be presented in the next section.

\section{Results}

\subsection{What Knowledge Workers Expect of R\&D Managers}

Knowledge workers, including project managers, were asked to indicate how they wanted to be lead. Their unanimous expectation was to work autonomously on their assigned task. Although they preferred autonomy, they did not want to be completely left alone; they expected to work independently within constrains. Most also expressed that they expected the managers to follow up on them, give them feedback, and if necessary correct their direction if they were drifting too far from their objective. A representative account of this sentiment is given by Sonny, one of the interviewed knowledge workers. Please note that the anonymity of the informants is secured by giving them cover names.

“... I want that the leader in one way gives me responsibility and a free hand, but that he or she, at the same 
time, places clear demands and follows up the things one asks of ... A good leader is one who has control, and knows what is going on around here. ... And also, he also ought to have human qualities as well. Yes, some empathy, understand people."

When asked to characterize a good leader, a few of the knowledge workers also emphasized the importance of the manager's technical competence. However, the importance of this competence was not related to an expectation that the manager should provide detailed technical advice, but as a prerequisite for the managers to maintain an overview of what people were working on. In contrast, surprisingly many focused on the importance of the managers possessing human skills. A good leader should be emphatic, understand human nature, be easy to talk with, have time to talk, and know employees as complete persons. They did not expect a manager to solve their private problems, but they expected to be able to talk about private and sensitive issues with the expectation that the manager would try to shield them from excessive work demands during rough periods. The following statement from Lars, an employee with project management responsibilities, is representative.

“... I expect, at least, that [the line manager] is a person I can relate to on a more human term than is necessary with others. To who I can discuss different matters, my well being, how things are experienced in the project ... I don't expect the line manager to, to be a discussion partner, on a private term. But if personal matters should come to interfere with the work, then it is naturally to talk about, to inform, explain and discuss it."

\subsection{R\&D Managers Understanding of Expectations towards Them}

$R \& D$ managers on different levels were asked to explain how they wanted to lead others. Their responses can be grouped in three areas: delegating work to autonomous employees, ensuring that they are doing well, and taking responsibility for organizing the work environment.

All managers wanted to delegate tasks and assignments to autonomous subordinates, but at the same time offer themselves as a sounding board and conversation partner. However, several managers pointed out that it was necessary to take individual consideration into account during the assignment process. Managers at all levels considered getting to know each other as very important, and making sure that their employees were doing well. One manager expressed that one way of doing this was to organize the conditions surrounding the knowledge workers like equipment, resolving administrative issues, and prioritizing tasks for them. Several managers also perceived that knowledge workers expected them to be present and provide attention. This is well expressed by Greg, a second level manager.

"They expect presence ... that you actually are physically present, they expect to see me, to use that expression ... I think they expect that you should have time for them, like, care about them, and they expect also that I shall prioritize what they should be doing, or what they should not be doing."

As noted by many knowledge workers and managers, it is important for managers to know their people. Here, Andrew, a first line manager, explained why and what kind of knowledge about his employees he feels he needs to know.

"It's okay that people care about how they are as persons, and when they are at home. It's a lot of things like that you need to know when you consider how much work to put on people, what kind of situation they are in. Therefore I see that as an essential point to have a fairly good sense of the social situation of people. I know when people have small kids at home, and if they get too preoccupied with their work I tell them to buzz off back home, 'you can't be sitting here and be working overtime now, now it's time for you to take care for your family."

All first-line managers wanted to know both about their employees' work and home lives to balance the amount of work with their current life situation. Because these managers had the responsibility to assign people to different projects and to approve the use of overtime, they were in a position to intervene on behalf of the knowledge workers. The following statements from first-line managers Steve illustrate the connections.

"I try to, I shall be available to people with problems. And I have, I readily invite people to come and tell me if they have problems ... And then I know about the situations, so if anything arises, then I can shield them to a certain degree."

\subsection{What R\&D Managers do to Fulfil Expectations from Knowledge Workers}

"The personnel responsibility, which is perhaps the hardest part in this job, is solved mainly by being around to check how people are doing and listening to how they are doing with their project work."

As the statement from Steve, a first line-manager, illustrates, listening is an important managerial activity. This 
activity, together with chatting, is two of the main ways managers get to know their employees. During the weeks of shadowing, there were numerous situations when the observed managers engaged in chatting or informal small talk with their colleagues. Sometimes it was the colleague who took the initiative, but most of the time the manager took the initiative. For example, Andrew stopped by each of his five assigned colleagues on a regular basis to check on them by asking "How are you doing?" This introduction encourages the colleague to bring up not only any work-related issue for discussion, but also more private matters. These status rounds of walking from office to office were consciously enacted and gave the manager valuable information and a good opportunity to exchange feedback.

So far we have a picture of R\&D managers who are involved and knowledgeable about knowledge workers' personal and family lives. This knowledge is attained by mundane activities like listening and chatting. However, having knowledge about people does not say anything about their emotional attitude towards others at work. The traditional picture of managers as rational and professional beings does not provide room for managers to have feelings for their employees. During the weeks of shadowing, two particular events stand out as sharp contrasts to the traditional picture. Two of the managers from different companies, interacted with employees on sick leave, and one of the events will now be described in detail.

Henry, a line manger, is sitting in his office when he picks up the phone and starts to dial a number. He tells me that he is calling Colin, one of his employees on long-term sick leave. I cannot listen in on what Colin says; I only hear what Henry is telling him. Henry's voice is more soft-spoken than usual. He starts with a greeting, and asks Colin how things are. Apparently he has just returned back home after a hospital admission. Henry does not say very much, he just listens to Colin's history and lets him steer the conversation. As far as I can tell Colin talks about his treatment, his prognosis and his state of health. Throughout the conversation Henry expresses understanding, empathy, and care. He asks a number of follow-up questions before telling Colin what the unit has been working on since the last time they spoke. Colin listens and asks Henry to tell him more about the activities in the different projects. Towards the end of the conversation, Henry airs the possibility for Colin to come by at work some time. Colin apparently answers that it would take some more time before he is able, but he wants to come. Before hanging up, Henry makes the promise to send out an e-mail to the unit on behalf of Colin. Henry looks exhausted, moved and quite concentrated. The phone conversation lasts for about 20 minutes.

The above event illustrates nicely how care can be expressed through the mundane activities of listening and chatting. However, it is important to note that observations of listening and chatting cannot be taken as evidence of a caring relationship between a manager and a knowledge worker. In this case, Henry talked about his feelings towards Colin and employees in general during an interview. The combination of observations and interviews is necessary to convincingly claim that managers can care about their employees. The following interview also illustrates the general sentiment among R\&D managers towards knowledge workers.

"I have one, who unfortunately has gotten a serious cancer diagnosis, who is 63. What we did then, we sent flowers before we knew he got cancer. I have visited him at home; we have talked over the phone several times. The unit sponsored an iPod, which we filled with music through some volunteering here. It is very important for me in relations with him, whom I am very fond off, and I do not try to hide that I think it is important towards the others that we show that we really care about him. It is important for the employees here to see that if they come in the same situation, that the workplace cares about you. I genuinely care about him, but I know in the back of my head that it serves more than one purpose. "

This last sentence above illustrates that caring activities have the potential to influence others. When the managers were asked about how they could influence others, they all acknowledged that they had influence, and gave examples of activities that they engaged in. The examples given were about being sociable, cheerful, and a solid supporter; giving individual consideration; and "walk the talk." However, managers did not seem to be particularly articulate about the influence process and how they influenced others. Therefore, in the next section we turn to Cialdini's (2001) description of social influence tactics.

\subsection{Analysis of Social Influence}

In R\&D organizations Cialdini's (2001) liking dimension is both relevant and important. People prefer to say yes to individuals they know and like. Liking is influenced by physical attractiveness, similarity, increased familiarity through repeated contact, and association. In R\&D organizations in this study, where managers are promoted from the ranks of knowledge workers, similarity is ensured based on similar educational backgrounds. If the managers also have worked previously within the same unit, then they share much common experience and history with the other knowledge workers. 
The R\&D managers spend much time with their subordinates and are usually available for short exchanges of information or requests. The manager and knowledge workers participate in many common activities and meetings, both formal and informal, where they can interact and observe each other. Especially in the more informal settings like lunch and coffee breaks, talking about leisure-time interest can highlight common interests, or at least provide a fuller picture of the persons they are dealing with. When knowledge workers observe through public e-mails, common activities, or in conversation that a manager cares about another person, these observations could strengthen the liking of this manager and thus be a source of influence. A strengthened liking helps to build trust, while increasing contact with people one already likes increase the amount of liking that person. Heightened liking could later lead to higher cooperation when the manager asks for a favour or makes assignments.

Showing care can also be understood through two other sources of influence: reciprocation and social proof. Cialdini (2001) identified reciprocation as a powerful process which influences by making people feel psychologically obliged to return favours. When a manager is doing some kind of favour, knowledge workers could feel obliged to return the favour by working harder or longer. In this case, it is possible to argue that in addition to the employee that receives attention and care from the manager, other employees who observe or are aware of this exchange can feel psychologically obliged to work harder. Because employees notice the manager's caring behaviour, they might expect equal favours and treatment if they find themselves in similar situations. Thus, the belief in potential future favours could influence them to feel higher degree of commitment towards the manager.

Social proof works as influence because of our tendency to observe what other people are doing as a means to decide our own actions (Cialdini, 2001). Doing observable favours could stimulate a more helpful environment among employees. The employees could emulate the managers' acts of doing favours and increasingly help others. It is also possible that the managers could act as role models; note that Henry, took initiative to include some of the employees in the activities to illustrate care and concern. This could be interpreted as an effort to not only encourage other employees to be more caring towards Colin, but also to other employees in the community. Social proof could also explain how the managers can act as role models by showing cheerfulness and "walk the talk."

Influence through scarcity is another possibility to why emotional support from the manager is perceived as valuable. A manager's attention is limited, and with this responsibility brings along a number of mandatory activities and meetings. According to Cialdini (2001), the scarcity principle makes items or opportunities more valuable to us when they are more rare and less available. In our setting, this would mean that mundane activities together with the manager is perceived as more valuable when the manager has less time to spare. This would also lead to a perception where the manager's attention is seen as more valuable when the demand for attention increases. Attention from the manager should therefore be more valued if the manager has personnel responsibility for a larger group of people than a smaller group. In the same manner, demands for a manager's attention would also increase if the manager is not always present at the location of work. Because workers have many colleagues but only one manager, they would value the manager's attention more than attention from others. Because of scarcity, more value would be placed on listening and chatting conducted by the manager compared to others.

Although the managers in this study worked to reduce power differentials, they cannot escape their position as manager and members of the management. Their occupation is embedded with authority through their title, and the title alone can increase compliance (Cialdini, 2001). The paradox of working to reduce power differences is that such work actually confirms that differences in status exist. If all employees were equal there would be nothing to play down. It seemed like all managers appeared to be similar to the knowledge workers, and thus downplayed the status difference during lunch or other informal settings by engaging in non-work related topics. However, by the end of the day it is still the managers that assign knowledge workers to their project and negotiate their salary. The manager can be seen as both a person and a position.

\section{Discussion}

The interviews in this study support previous findings that knowledge workers value autonomy (Mumford et al., 2002; Oldham \& Cummings, 1996) and dislike to be directed by a supervisor (McAuley et al., 2000). However, it should be noted that knowledge workers expected autonomy within predefined constrains and managers that followed up on them and showed interest in their work. This can be interpreted as a need for affirmation of the value of their work, which could also explain their focus on emotional support from their manager.

The R\&D managers in this study were working in matrix-organization and they did not have the day-to-day 
responsibility for completing projects. This situation means that relationship-oriented actions should be more profound than technical- and task-oriented actions. Because the R\&D managers have personnel responsibility in the matrix organization, they have authority to approve how much the knowledge workers actually work in the projects. As the analysis above shows, ordinary activities like listening and chatting, as well as caring for someone, can influence others through social influence processes. The perceived importance of these activities by the manager echoes the findings in Alvesson and Sveningsson (2003), and also confirms that also subordinates attach high significance to these activities in spite of the expectation by Alvesson and Sveningsson (2003, p. 1455).

As noted by Alvesson and Sveningsson (2003), all people can influence each other, so why are mundane activities conducted by managers viewed as more important than others? The social processes of scarcity and authority are part of the answer given in the analysis. However, even more important in these particular research settings is the first-line managers' authority to regulate the knowledge workers' hours of work. Therefore these managers have the means to shield, and if necessary, provide custom-made working arrangements for knowledge workers living through rough personal situations. This means that when knowledge workers are talking to their manager about problems at work or at home, they are not talking to just anyone. They are talking to someone that can actually intervene and make a decision that can have an impact and help them.

In spite of accounts of corporate life as a web of intrigues (Jackall, 1988), leaders are capable of genuinely caring for their employees. However, caring for others and behaving with care towards employees do not necessarily exclude the potential influence from this behaviour. At the same time as leaders can feel concern for others, they can also notice the positive, yet instrumental, influence their action can have on employees as Henry mentioned in the interview. This has also been noticed by Kunda who reported that a manager told project managers to get to know their employees and show care and concern towards them to prevent burnout: "we need them for a long, long time" (1992, pp. 203-204). This can also be seen as an example of normative control, which Kunda (1992, p. 11) defines as an effort to direct organizational members by controlling the underlying experience, thoughts and feelings that guide their actions. It is beyond the scope of this article to examine this subject further, but future studies could continue the effort to relate influence and normative control to mundane managerial activities like listening and chatting.

This study has highlighted the importance of emotions and indirect influence in the leadership process. This view is in accordance with Fineman (2000, p. 11), who noticed that emotional processes may be unconscious. The implication of more focus on emotions in leadership studies is a growing need to acknowledge that behaviour can influence people both intentionally and unintentionally. This is important when studying managers' daily activities, because the effect of intentional and unintentional influence is difficult, if not impossible, to keep separate. More qualitative leadership studies are needed to examine the impact from mundane leadership activities. According to Fineman (2000) and Barley and Kunda (2001), observational field methods, like ethnography and shadowing, have the potential to secure a sound empirical foundation for future theories about leadership.

Many more leadership studies within R\&D organizations are highly needed, but future research is recommended to broaden its focus away from just project groups and leaders to include other actors. This study has focused on the relationship between first-line R\&D managers and knowledge workers to examine more long-term effects in this organizational setting. Although the particular sample was chosen to highlight the importance of leadership support and emotions, even more detailed studies on different groups of actors is recommended for the future. However, it should be emphasized that even support and care can potentially be used to influence others in negative and unwanted directions. Future studies should also be encouraged to further examine how supporting leader behavior, like care, can influence others and in what extent managers apply such behavior consciously or unconsciously.

It is well known that qualitative research is not suited for broad generalizations. The empirical material in this study is drawn from two R\&D organizations, and is therefore not suitable for generalization to all managers. However, the main strength and contribution of qualitative research is to provide insightful examples and analysis (Conger, 1998). The empirical findings provide examples from a particular organizational context that can provide insights of more general interest. In this study, the empirical data is presented in a rather detailed manner to help the reader to decide if the interpretation and analysis are transferable.

The main conclusion from this article is that care expressed through ordinary activities like listening and chatting can influence others. R\&D leaders looking for influence can thus lead knowledge workers with care. However, both managers and employees need to be made aware that activities and behavior can influence others and that 
this can be both intentional and unintentional. Although all people can influence each other, managers' behavior is still considered to influence more than other people due to their position and formal authority. This is also one of the main explanations why knowledge workers, especially in this particular setting of $R \& D$, expected their manager to relate to and care for them. It is clear from the empirical findings in this study and the analysis of these findings, that manager's activities of care can indeed be a source of social influence. This also serves to illustrate the close connection between emotion and influence. This intertwinement should inspire future research to look deeper and broader for potential sources of influence in the leadership process, but also to acknowledge the importance of leadership in the setting of innovation.

\section{References}

Alvesson, M. (2000). Social Identity and the Problem of Loyalty in Knowledge-Intensive Companies. Journal of Management Studies, 37, 1101-1124. http://dx.doi.org/10.1111/1467-6486.00218

Alvesson, M. (2004). Knowledge Work and Knowledge-Intensive Firms. Oxford: Oxford University Press.

Alvesson, M., \& Sveningsson, S. (2003). Managers Doing Leadership: The Extra-Ordinarization of the Mundane. Human relations, 56(12), 1435-1459. http://dx.doi.org/10.1177/00187267035612001

Barley, S. R., \& Kunda, G. (2001). Bringing Work Back In. Organization science, 12(1), 76-95. http://dx.doi.org/10.1287/orsc.12.1.76.10122

Bass, B. M. (1985). Leadership and performance beyond expectations. New York: Free Press.

Bass, B. M. (1990). Bass \& Stogdill's handbook of leadership: theory, research, and managerial applications (3nd ed.). New York: Free Press.

Bass, B. M., \& Avolio, B. J. (1990). Developing transformational leadership: 1992 and beyond. Journal of European Industrial Training, 14(5), 21-27. http://dx.doi.org/10.1108/03090599010135122

Bryman, A. (2004). Qualitative research on leadership: A critical but appreciative review. The Leadership quarterly, 15(6), 729-769. http://dx.doi.org/10.1016/j.leaqua.2004.09.007

Bryman, A. (2008). Social research methods (3rd ed.). Oxford; New York: Oxford University Press.

Burns, J. M. (1978). Leadership. New York: Harper \& Row Publishers.

Cialdini, R. B. (2001). Influence: Science and Practice (Fourth ed.). Boston, MA: Allyn and Bacon.

Conger, J. A. (1998). Qualitative research as the cornerstone methodology for understanding leadership. The Leadership Quarterly, 9(1), 107-121. http://dx.doi.org/10.1016/S1048-9843(98)90044-3

Dasborough, M. T. (2006). Cognitive asymmetry in employee emotional reactions to leadership behaviors. The Leadership Quarterly, 17(2), 163-178. http://dx.doi.org/10.1016/j.leaqua.2005.12.004

Dasborough, M. T., \& Ashkanasy, N. M. (2002). Emotion and attribution of intentionality in leader-member relationships. The Leadership Quarterly, 13(5), 615-634. http://dx.doi.org/10.1016/S1048-9843(02)00147-9

Eisenhardt, K. M. (1989). Building Theories from Case Study Research. The Academy of Management Review, 14(4), 532-550. http://dx.doi.org/10.2307/258557

Elkins, T., \& Keller, R. T. (2003). Leadership in research and development organizations: A literature review and conceptual framework. The Leadership Quarterly, 14(4-5), 587-606. http://dx.doi.org/10.1016/S1048-9843(03)00053-5

Farris, G. F. (1988). Technical Leadership: Much discussed but little understood. Research Technology Management, 31(2), 12-16.

Fineman, S. (2000). Emotional Arenas Revisited. In S. Fineman (Ed.), Emotion in Organizations (2nd ed. pp. 1-24). London: Sage Publications. http://dx.doi.org/10.4135/9781446219850.n1

George, J. M. (2000). Emotions and leadership: The role of emotional intelligence. Human relations, 53(8), 1027-1055. http://dx.doi.org/10.1177/0018726700538001

Hargie, O., Dickson, D., \& Tourish, D. (1999). Communication in Management. Aldershot: Gower.

Hatfield, E., Cacioppo, J. T., \& Rapson, R. L. (1993). Emotional Contagion. Current Directions in Psychological Science, 2(3), 96-99. http://dx.doi.org/10.1111/1467-8721.ep10770953

Higgins, C. A., Judge, T. A., \& Ferris, G. R. (2003). Influence tactics and work outcomes: a meta-analysis. 
Journal of Organizational Behavior, 24(1), 89-106. http://dx.doi.org/10.1002/job.181

Humphrey, R. H. (2002). The many faces of emotional leadership. The Leadership Quarterly, 13(5), 493-504. http://dx.doi.org/10.1016/S1048-9843(02)00140-6

Jackall, R. (1988). Moral Mazes: The World of Corporate Managers. New York: Oxford University press.

Judge, W. Q., Fryxell, G. E., \& Dooley, R. S. (1997). The new task of R\&D management: Creating goal-directed communities for innovation. California Management Review, 39(3), 72-85.

Jung, D. I., Chow, C., \& Wu, A. (2003). The role of transformational leadership in enhancing organizational innovation: Hypotheses and some preliminary findings. The Leadership Quarterly, 14(4-5), 525-544. http://dx.doi.org/10.1016/S1048-9843(03)00050-X

Kunda, G. (1992). Engineering Culture. Control and commitment in a high-tech corporation. Philadelphia: Temple University Press.

Kvale, S. (1996). Interviews: An introduction to qualitative research interviewing. Thousand Oaks, Calif.: Sage.

Mayeroff, M. (1971). On Caring. New York: Harper and Row.

McAuley, J. L., Duberley, J., \& Cohen, L. (2000). The meaning professionals give to management... and strategy. Human relations, 53(1), 87-116. http://dx.doi.org/10.1177/0018726700531005

McDonald, S. (2005). Studying action in context: a qualitative shadowing method for organizational research. Qualitative Research, 5(4), 455-473. http://dx.doi.org/10.1177/1468794105056923

Mintzberg, H. (1973). The Nature of Managerial Work. New York: Harper \& Row, Publishers.

Mintzberg, H. (1998). Covert leadership: notes on managing professionals. Knowledge workers respond to inspiration, not supervision. Harvard business review, 76(6), 140-147.

Mumford, M. D., \& Licuanan, B. (2004). Leading for innovation: Conclusions, issues, and directions. The Leadership Quarterly, 15(1), 163-171. http://dx.doi.org/10.1016/j.leaqua.2003.12.010

Mumford, M. D., Scott, G. M., Gaddis, B., \& Strange, J. M. (2002). Leading creative people: Orchestrating

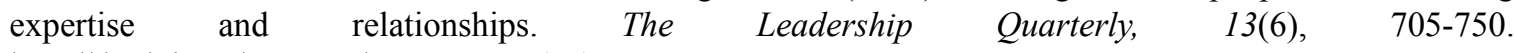
http://dx.doi.org/10.1016/S1048-9843(02)00158-3

Oldham, G. R., \& Cummings, A. (1996). Employee Creativity: Personal and Contextual Factors at Work. Academy of Management journal, 39(3), 607-634. http://dx.doi.org/10.2307/256657

Pirola-Merlo, A., Härtel, C., Mann, L., \& Hirst, G. (2002). How leaders influence the impact of affective events on team climate and performance in R\&D teams. The Leadership Quarterly, 13(5), 561-581. http://dx.doi.org/10.1016/S1048-9843(02)00144-3

Sashkin, M. (2004). Transformational leadership approaches: A review and synthesis. In J. Antonakis, A. T. Cianciolo \& R. J. Sternberg (Eds.), The Nature of leadership (pp. 171-196). Thousand Oaks, Calif.: Sage.

Scott, S. G., \& Bruce, R. A. (1998). Following the leader in R\&D: The joint effect of subordinate problem-solving style and leader-member relations on innovative behavior. IEEE Transactions on Engineering Management, 45(1), 3-10. http://dx.doi.org/10.1109/17.658656

Solomon, R. C. (1998). The moral psychology of business: Care and compassion in the corporation. Business Ethics Quarterly, 8(3), 515-533. http://dx.doi.org/10.2307/3857435

Vie, O. E. (2010). Have post-bureaucratic changes occurred in managerial work? European Management Journal, 28(3), 182-194. http://dx.doi.org/10.1016/j.emj.2009.11.005

Von Krogh, G. (1998). Care In Knowledge Creation. California Management Review, 40(3), 133-153.

Von Krogh, G., Ichijo, K., \& Nonaka, I. (2000). Enabling knowledge creation. How to Unlock the Mystery of Tacit Knowledge and Release the Power of Innovation. New York: Oxford University Press.

Yin, R. K. (2002). Case Study Research: Design and methods (3th ed.). Thousand Oaks, CA: Sage Publications.

Yukl, G. (2002). Leadership in organizations (5th ed.). Upper Saddle River, N.J.: Prentice Hall.

Yukl, G., Seifert, C. F., \& Chavez, C. (2008). Validation of the extended Influence Behavior Questionnaire. The Leadership quarterly, 19(5), 609-621. http://dx.doi.org/10.1016/j.leaqua.2008.07.006 